\title{
GENDER DIFFERENCES IN PROXIMAL ESOPHAGEAL CONTRACTIONS
}

\author{
Roberto Oliveira DANTAS, Leda Maria Tavares ALVES and Rachel de Aguiar CASSIANI
}

\begin{abstract}
Context - There are reports showing that gender has an influence on swallowing and on the contractions of the distal esophageal body. Objective - In this investigation we studied the effect of gender on proximal esophageal contraction. Methods - We studied 20 men (22-68 years old, median 39 years) and 44 women (18-61 years old, median 41 years) without symptoms and without gastrointestinal or respiratory diseases. We measured the time interval between the onset of pharyngeal contraction $1 \mathrm{~cm}$ proximal to the upper esophageal sphincter and the onset of the proximal esophageal contraction $5 \mathrm{~cm}$ from the pharyngeal recording. We also measured the amplitude, duration and area under the curve of the proximal esophageal contractions. The recording was performed by the manometric method with continuous perfusion. The contractions were recorded in duplicate after swallows of a $5 \mathrm{~mL}$ bolus of water. Results - There were no differences between men and women in the interval between the onset of pharyngeal and of esophageal contractions or in the amplitude of esophageal contractions. The duration of contractions was longer in women $(2.35 \pm 0.60 \mathrm{~s})$ than in men $(2.07 \pm 0.62 \mathrm{~s})$ but the difference did not reach statistical significance $(P=0.087)$. The area under the curve of the esophageal contraction was higher in women $(130.2 \pm 55.2 \mathrm{~mm} \mathrm{Hg} \mathrm{x} \mathrm{s})$ than in men $(97.4 \pm 49.4 \mathrm{~mm} \mathrm{Hg} \mathrm{x} \mathrm{s,} P=0.026)$. Conclusion - We conclude that there is a difference between men and women in the proximal esophageal contractions in response to wet swallows, although this difference is of no clinical relevance.
\end{abstract}

HEADINGS - Esophagus, physiology. Gender identity.

\section{INTRODUCTION}

There are reports showing that women ingest water at a lower flow ${ }^{(1,12)}$, with a smaller volume in each swallow $^{(1,12)}$, and have a longer oropharyngeal transit duration $^{(9)}$ than men.

Women have a longer duration of upper esophageal sphincter (UES) opening ${ }^{(17,22)}$, longer pressure duration in the oropharyn $x^{(19)}$ and longer duration of esophageal contraction in the distal esophageal body ${ }^{(6)}$ than men. These results suggest that women have a different response to wet swallows in the proximal digestive tract compared to men.

In this investigation we studied the contractions in the proximal esophageal body, which has a predominance of striated muscles fibers, in contrast to the distal esophageal body, which consists exclusively of smooth muscle ${ }^{(14)}$. The objective was to compare the proximal esophageal contractions in men and women. Our hypothesis is that differences in proximal esophageal contractions may be involved in differences in swallowing between genders.

\section{METHODS}

We studied proximal esophageal contraction in 64 normal volunteers without gastrointestinal or neurologic diseases and without dysphagia, respiratory symptoms or proximal digestive symptoms. They were 20 men aged 22-68 years (mean: $42.5 \pm 15.4$ years, median: 39.5 years) and 44 women aged 18-61 years (mean: $40.9 \pm 12.9$ years, median: 41.0 years).

We evaluated the proximal esophageal contraction by the manometric method. The examination was performed with a round eight-lumen polyvinyl catheter with an outer diameter of $4.5 \mathrm{~mm}$ and an inner diameter of $0.8 \mathrm{~mm}$ (Arndorfer Specialities, Inc, Greendale, Wisconsin, USA). The four proximal lateral openings of the catheter were spaced $5 \mathrm{~cm}$ apart at $90^{\circ}$ angles. They were connected to external pressure transducers (pvb Medizintechnik GmbH, Kirchseeon, Germany), which in turn were connected to a PC Polygraph HR (Synectics Medical, Stockholm, Sweden). The manometric signals were stored in a computer. During the manometric recordings, a minimally compliant pneumohydraulic pump (JS Biomedicals, Ventura, CA, USA) perfused distilled water at $0.5 \mathrm{~mL} / \mathrm{min}$ through each lumen.

All individuals were studied in the supine position after 12 hours of fasting. The catheter was introduced through the nose. The response of the proximal esophagus to a $5 \mathrm{~mL}$ bolus of water was analyzed with the proximal opening of the catheter located $1 \mathrm{~cm}$ above the UES and the other opening located $5 \mathrm{~cm}$ from the proximal opening. Two swallows were performed with an interval

Department of Medicine, "Faculdade de Medicina de Ribeirão Preto, Universidade de São Paulo", Ribeirão Preto, SP.

Correspondence: Prof. Roberto Oliveira Dantas - Departamento de Clínica Médica - Faculdade de Medicina de Ribeirão Preto - USP - 14049-900 - Ribeirão Preto, SP, Brazil. E-mail: rodantas@fmrp.usp.br 
of at least 30 seconds between them. The result for each subject was the mean of the two measurements.

Using the computer Polygram Upper GI software version 6.4 (Gastrosoft, Stockolm, Sweden) we measured the time between the onset of the pharyngeal contractions $1 \mathrm{~cm}$ above the UES and the onset of the esophageal contractions 5 $\mathrm{cm}$ from the pharyngeal contractions (PET), as well as the amplitude, duration and area under the curve (AUC) of the esophageal contractions (Figure 1).

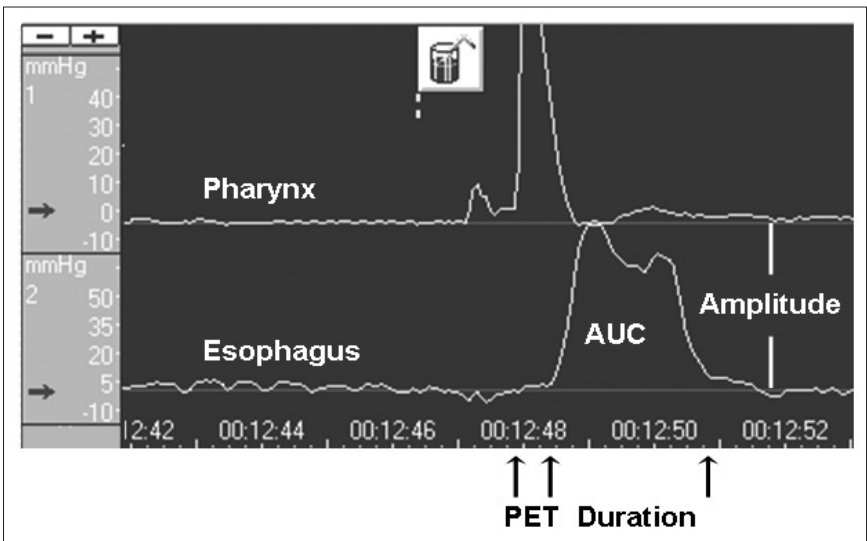

FIGURE 1. Pharyngeal and proximal esophageal contraction of a normal male volunteer showing the pharyngeal-esophageal time (PET) and the amplitude, duration and area under the curve (AUC) of the proximal esophageal contraction. The distance from the pharyngeal to the esophageal recording is $5 \mathrm{~cm}$

The study was approved by the Human Research Committee of the University Hospital of Ribeirão Preto, SP, Brazil. Written informed consent was given by all subjects.

Data were analyzed statistically by the unpaired Student $t$-test. Differences were considered significant when $P<0.05$. The results are reported as mean, standard deviation (SD), median and 95\% confidence interval.

\section{RESULTS}

There was no difference between men and women in pharyngeal-esophageal time (PET) or in the amplitude of proximal esophageal contractions $(P>0.30$, Table 1$)$.

The duration of proximal esophageal contractions was shorter in men than in women, but the difference did not reach statistical significance $(P=0.087$, Table 1$)$. Sixteen percent of women had a contraction duration of more than 3 seconds compared with $5 \%$ of men (Table 2). The area under the curve (AUC) of contractions was smaller in men than in women $(P=0.026$, Table 1$)$. Nine percent of women had an AUC above $200 \mathrm{~mm} \mathrm{Hg} \mathrm{x} \mathrm{s,} \mathrm{but} \mathrm{all} \mathrm{men} \mathrm{had} \mathrm{an} \mathrm{AUC} \mathrm{below}$ $200 \mathrm{~mm} \mathrm{Hg}$ x s (Table 2).

TABLE 2. Distribution of subjects regarding duration of contractions and area under the curve (AUC) of contractions, in percentage

\begin{tabular}{|c|c|c|c|c|c|c|c|}
\hline & \multicolumn{4}{|c|}{ DURATION(S) } & \multicolumn{3}{|c|}{$\operatorname{AUC}(\mathrm{mm} \mathrm{Hg} \times \mathrm{s})$} \\
\hline & $0-1.0$ & $1.1-2.0$ & $2.1-3.0$ & $3.1-4.0$ & $0-100$ & $101-200$ & $201-300$ \\
\hline Men & 10 & 25 & 60 & 5 & 55 & 45 & 0 \\
\hline Women & 0 & 27 & 57 & 16 & 34 & 57 & 9 \\
\hline
\end{tabular}

The individual results regarding duration of proximal esophageal contractions and AUC of contractions are shown in Figures 2 and 3, respectively.

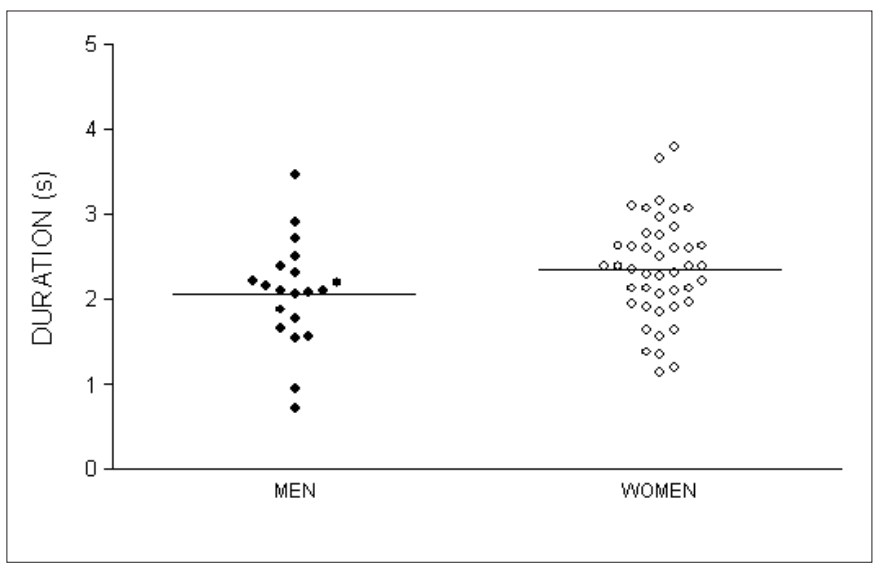

FIGURE 2. Duration of proximal esophageal contractions in men and women. The horizontal bar represents the mean. $P=0.087$

\section{DISCUSSION}

We found that the contraction performance of the proximal esophagus is not the same in men and women. The result of the product of amplitude and duration of contractions was higher in women than in men.

Previous reports have shown differences between men and women in the motility of the proximal digestive tract. Differences have been observed in water ingestion ${ }^{(1,12)}$,

TABLE 1. Pharyngeal-esophageal time (PET), amplitude, duration and area under the curve (AUC) of proximal esophageal contractions in men (n $=20)$ and women $(n=44)$

\begin{tabular}{|c|c|c|c|c|c|c|}
\hline & \multicolumn{2}{|c|}{ MEN } & \multicolumn{2}{|c|}{ WOMEN } & \multirow{2}{*}{$\begin{array}{c}95 \% \text { Confidence } \\
\text { interval }\end{array}$} & \multirow[b]{2}{*}{$P$} \\
\hline & Mean \pm SD & Median & Mean \pm SD & Median & & \\
\hline PET (s) & $0.79 \pm 0.18$ & 0.77 & $0.82 \pm 0.18$ & 0.79 & $-0.13 \leftrightarrow 0.07$ & 0.543 \\
\hline Amplitude ( $\mathrm{mm} \mathrm{Hg}$ ) & $96.8 \pm 51.1$ & 97.9 & $107.1 \pm 41.2$ & 97.7 & $-34.31 \leftrightarrow 13.68$ & 0.393 \\
\hline Duration (s) & $2.07 \pm 0.62$ & 2.10 & $2.35 \pm 0.60$ & 2.34 & $-0.62 \leftrightarrow 0.04$ & 0.087 \\
\hline $\operatorname{AUC}(\mathrm{mm} \mathrm{Hg} \times \mathrm{s})$ & $97.4 \pm 49.4$ & 97.7 & $130.2 \pm 55.2$ & 114.9 & $-61.60 \leftrightarrow-3.96$ & 0.026 \\
\hline
\end{tabular}




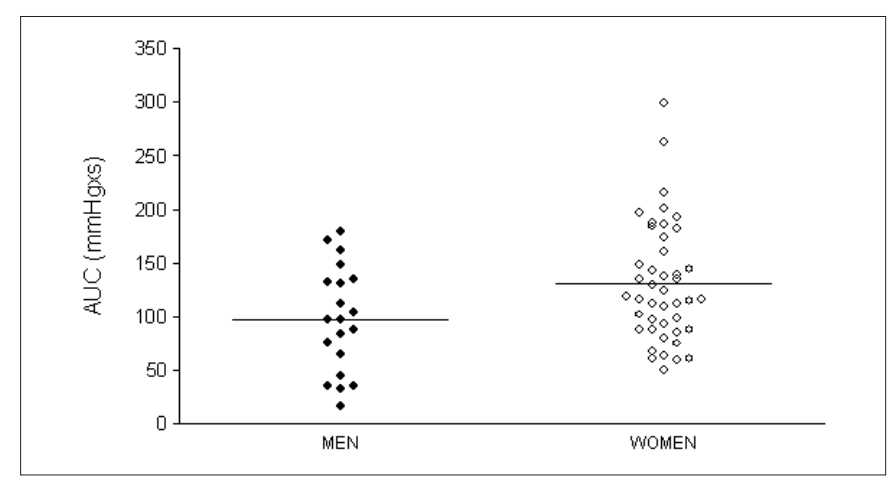

FIGURE 3. Area under the curve (AUC) of proximal esophageal contractions in men and women. The horizontal bar represents the mean. $P=0.026$

oropharyngeal transit( ${ }^{(9)}$, UES opening duration ${ }^{(17,22)}$, pressure duration in the oropharynx with swallows ${ }^{(19)}$, duration of distal esophageal contractions ${ }^{(6)}$, and gastric emptying of solid food ${ }^{(13,15)}$. These results showed that women have a longer transit, contraction duration, UES opening and gastric emptying than men.

The explanation for the results observed may be anatomic and/or hormonal differences between genders. Postmenopausal women on hormone replacement therapy exhibited a delay in gastric emptying similar to that observed in premenopausal women $^{(13)}$. Reduced gastrointestinal smooth muscle contractility has been attributed to the presence of female reproductive hormones ${ }^{(3)}$. The gastric contractility measured in the midantrum was significantly lower for women ${ }^{(15)}$.

We observed previously a difference between women and men in the contractility of the distal esophageal body ${ }^{(6)}$, which exclusively contains smooth muscle ${ }^{(14)}$. In this paper we described similar results in the proximal esophageal body, where there is striated muscle in the cranial part of both longitudinal and circular muscle layers that is gradually replaced by smooth muscle cells caudally ${ }^{(14)}$. Esophageal striated muscle receives dual innervation from both vagal nerve fibres originating in the brain stem and varicose enteric nerve fibres originating in myenteric ganglia ${ }^{(14,18)}$.
If female reproductive hormones have any action on the smooth muscle of the digestive tract, they may also have an action on the proximal esophageal body which contains some amount of smooth muscle fibres ${ }^{(14)}$. Eighteen $(41 \%)$ of the women studied here were older than 45 years, and therefore the presence of female reproductive hormones may not be a complete explanation for the results.

The other possibility is anatomic differences between genders $^{(11)}$. This should be the explanation for the differences seen in swallowing ${ }^{(9)}$. The masseter muscle has a predominance of type II fibres in males and of type I fibres in females ${ }^{(23)}$. To our knowledge, there is no reference about anatomic or functional differences in esophageal innervation between men and women.

The present results suggest the hypothesis that women may have some delay in transit through the esophageal transition $z e^{(5)}$. In this esophageal segment, at the aortic arch level, the proximal striated muscle changes to distal smooth muscle and in some subjects there is no contraction in this transition ${ }^{5}$, 16), with consequent retention in the proximal esophagus ${ }^{(4,}$ 10). A situation that causes difficulty in esophageal transit is associated with an increase in contraction duration and in the AUC of contractions ${ }^{(2,21)}$.

The small difference observed between men and women did not cause any problems. Both genders have normal swallowing behaviour and normal esophageal contraction, with no difficulty when eating liquid or solid foods. The physiological system that controls esophageal contraction can function with some variability that does not cause symptoms. The amplitude and duration of contractions observed here in the proximal esophageal body were similar to our previous results obtained with normal volunteers ${ }^{(7,8,20)}$. The importance of the knowledge of these differences is to understand the possibility of different behaviours during drinking and eating and in the recovery from diseases which cause dysphagia. We should also consider gender when we perform evaluations and studies about swallowing, esophageal motility or gastric emptying.

We conclude that there is a difference between men and women in the proximal esophageal contraction in response to wet swallows, which, however, does not have clinical importance.

Dantas RO, Alves LMT, Cassiani RA. Influência do gênero nas contrações do esôfago proximal. Arq Gastroenterol. 2009;46(4):284-7.

RESUMO - Contexto - Há trabalhos que demonstram a existência de diferenças entre homens e mulheres na deglutição e nas contrações em parte distal do esôfago. Objetivo - Neste trabalho estuda-se a influência do gênero nas contrações em parte proximal do esôfago de pessoas assintomáticas. Método - Incluíram-se 20 homens (22-68 anos, mediana 39 anos) e 44 mulheres (18-61 anos, mediana 41 anos) sem doenças gastrointestinais, neurológicas ou respiratórias. Mediu-se o intervalo de tempo entre o início da contração em faringe $1 \mathrm{~cm}$ proximal ao esfíncter superior do esôfago e o início da contração em esôfago proximal $5 \mathrm{~cm}$ distal ao registro da faringe, e a amplitude, duração e área sob a curva da contração esofágica proximal. Utilizou-se o método manométrico com perfusão contínua. As contrações foram registradas em duplicata após a deglutição de $5 \mathrm{~mL}$ de água. Resultados - Não se observaram diferenças entre homens e mulheres no intervalo entre a contração da faringe e do esôfago proximal, e na amplitude da contração do esôfago. A duração da contração foi maior nas mulheres $(2,35 \pm 0,60 \mathrm{~s})$ do que nos homens $(2,07 \pm 0,62 \mathrm{~s})$ mas o resultado não atingiu significância estatística $(P=0,087)$. A área sob a curva das contrações esofágicas foi maior nas mulheres $(130,2 \pm 55,2 \mathrm{~mm} \mathrm{Hg} \times \mathrm{s})$ do que nos homens $(97,4 \pm$ 49,4 mm Hg x s, $P$ = 0,026). Conclusão - Observou-se que há diferença entre homens e mulheres nas contrações em esôfago proximal quando da deglutição de água, o que não deve ter importância clínica.

DESCRITORES - Esôfago, fisiologia. Identidade de gênero. 


\section{REFERENCES}

1. Alves LMT, Cassiani RA, Santos CM, Dantas RO. Gender effect on the clinical measurement of swallowing. Arq Gastroenterol. 2007;44:227-9.

2. Blom D, Bajag S, Liu J, Hofmann C, Rittmann T, Derksen T, Shaker R. Laparoscopic Nissen fundoplication decreases gastroesophageal junction distensibility in patients with gastroesophageal reflux disease. J Gastrointest Surg. 2005;9:1318-25.

3. Bruce LA, Behsudi FM, Danhof IE. Smooth muscle mechanical responses in vitro to bethanechol after progesterone in male rate. Am J Physiol. 1978;235:E422-8.

4. Dantas RO, Godoy RA, Meneghelli UG, Oliveira RB, Troncon LEA. Dysphagia lusoria and segmental aperistalsis in the upper third of the esophagus. J Clin Gastroenterol. 1985;7:522-4.

5. Dantas RO. The contractions in the esophageal transition zone. Am J Gastroenterol. 1995;90:1191-2.

6. Dantas RO, Ferriolli E, Souza MAN. Gender effects on esophageal motility. Braz J Med Biol Res. 1998;31:539-44.

7. Dantas RO, Aprile LRO. Esophageal striated muscle contractions in patients with gastroesophageal reflux symptoms. Dig Dis Sci. 2002;47:2586-90.

8. Dantas RO, Aprile LRO, Aben-Athar CG, Miranda ALM. Esophageal striated muscle contractions in patients with Chagas disease and idiopathic achalasia. Braz J Med Biol Res. 2002;35:677-83.

9. Dantas RO, Cassiani RA, Santos CM, Gonzaga GC, Alves LMT, Mazin SC. Effect of gender on swallow event duration assessed by videofluoroscopy. Dysphagia; 2009;24:280-4.

10. Ghosh SK, Janiak P, Fox M, Schwizer W, Hebbard GS, Brasseur JG. Physiology of the oesophageal transition zone in the presence of chronic bolus retention: studies using concurrent high resolution manometry and digital fluoroscopy. Neurogastroenterol Motil. 2008;20:750-9.

11. Gluckman A. Sexual dimorphism and mammalian biology and pathology. New York: Academic Press; 1981.

12. Hughes TA, Wiles CM. Clinical measurement of swallowing in health and in neurogenic dysphagia. Q J Med. 1996;89:109-16.
13. Hutson WR, Roehrkasse RL, Wald A. Influence of gender and menopause on gastric emptying and motility. Gastroenterology. 1989;96:11-7.

14. Kallmünzer B, Sörensen B, Neuhber WL, Wörl J. Enteric co-innervation of striated muscle fibers in human oesophagus. Neurogastroenterol Motil. 2008;20:597-610.

15. Knight LC, Parkman HP, Brown KL, Miller MA, Trate DM, Maurer AH, Fisher RS. Delayed gastric emptying and decreased antral contractility in normal premenopausal women compared with men. Am J Gastroenterol. 1997;92:968-75.

16. Li M, Brasseur JG, Dodds WJ. Analyses of normal and abnormal esophageal transport using computer simulations. Am J Physiol. 1994;266:G525-43.

17. Logemann JA, Pauloski BR, Rademaker AW, Kahrilas PJ. Oropharyngeal swallow in younger and older women: videofluoroscopic analysis. J Speech Lang Hear Res. 2002;45:434-45.

18. Neuhuber WL, Wörld J, Berthoud HR. Conte B. NADPH - diaphorase-positive nerve fibres associated with motor endplates in the rat esophagus: new evidence for co-innervation of striated muscle by enteric neurons. Cell Tissue Res. 1994;276:2330.

19. Perlman AL, Schultz JG, Van Daele DJ. Effect of age, gender, bolus volume, and bolus viscosity on oropharyngeal pressure during swallowing. J Appl Physiol. 1993;75:33-7.

20. Ramos RI, Varrica LMM, Dantas RO. Differences in response of the proximal esophagus to wet swallows in patients of Chagas' disease and idiopathic achalasia. Dis Esophagus. 2006;19:401-5.

21. Ren J, Dodds WJ, Martin CJ, Dantas RO, Mittal RK, Harrington SS, Kern MK, Brasseur JG. Effect of increased intra-abdominal pressure on peristalsis in feline esophagus. Am J Physiol. 1991;261:G417-25.

22. Robbins JA, Hamilton JW, Lof GL, Kempster GB. Oropharyngeal swallowing in normal adults of different ages. Gastroenterology. 1992;103:823-9.

23. Tuxen A, Bakke M, Pinholt EM. Comparative data from young men and women on masseter fibers, function and facial morphology. Arch Oral Biol. 1999;44:509-18.

Recebido em 22/12/2008 Aprovado em 7/4/2009. 